\title{
Imparcialidade judicial: uma breve análise sobre uma dimensão da conduta judicial
}

\author{
Judicial impartiality: a brief analysis on a dimension of judicial conduct \\ Imparcialidad judicial: un breve análisis de una dimensión de la conducta judicial
}

Recebido: 25/09/2021 | Revisado: 03/10/2021 | Aceito: 04/10/2021 | Publicado: 05/10/2021

\author{
José Bruno Martins Leão \\ ORCID: https://orcid.org/0000-0002-5797-4303 \\ Universidade Paranaense, Brasil \\ E-mail: jbmleao@gmail.com \\ Luiz Manoel Gomes Junior \\ ORCID: https://orcid.org/0000-0002-8111-4549 \\ Universidade Paranaense, Brasil \\ E-mail: luizm@luizmconsultoria.com.br \\ Miriam Fecchio Chueiri \\ ORCID: https://orcid.org/0000-0003-4658-5414 \\ Universidade Paranaense, Brasil \\ E-mail: miriamfecchio@uol.com.br
}

\begin{abstract}
Resumo
O trabalho tem como objetivo apresentar uma noção dogmática sobre o princípio da imparcialidade judicial, abordando-o, de início, sob a perspectiva do processo civil constitucional. Demais disso, por meio de revisão bibliográfica, buscou-se explicar a correspondência internacional do referido princípio como uma orientação de conduta judicial, trazendo a lume, para tanto, uma breve contribuição do direito transnacional, assim como um apanhado das principais diretrizes fornecidas pelos Princípios de Conduta Judicial de Bangalore. E, por conclusão, registrou-se as considerações extraídas de estudo empírico, a partir do qual se percebe o dever de imparcialidade como uma orientação dogmática de difícil implementação prática, em virtude do caráter humano do julgador, impossibilitando-o de total isenção valorativa. Dessa maneira, o ideal de atuação eminentemente imparcial se revelou apenas como uma orientação artificial de comportamento, em virtude de consistir num dever impraticável em sua totalidade, uma vez que não haveria possibilidade de se exigir de juízes, seres humanos, a desvinculação de percepções pessoais, experiências, princípios e valores particulares por ocasião da construção da decisão judicial. Por essa razão, a ideia da imparcialidade também pode ser apresentada como uma crença, com base na qual a sociedade mantém a mínima relação de confiança nos órgãos e nos agentes que integram o sistema de justiça.
\end{abstract}

Palavras-chave: Imparcialidade judicial; Princípio processual; Conduta judicial; Função jurisdicional; Independência.

\begin{abstract}
The work aims to present a dogmatic notion about the principle of judicial impartiality, addressing it, at first, from the perspective of the constitutional civil process. Furthermore, through bibliographic review, we sought to explain the international correspondence of this principle as an orientation of judicial conduct, bringing to light, a brief contribution of transnational law, as well as an overview of the main guidelines provided by the Principles of Judicial Conduct of Bangalore. And, by conclusion, we recorded the considerations extracted from empirical study, from which the duty of impartiality is perceived as a dogmatic orientation of difficult practical implementation, due to the human character of the judge, making him unable to fully exemption of value. Thus, the ideal of acting eminently impartial, was revealed only as an artificial orientation of behavior, due to consisting of an impractical duty in its entirety, since there would be no possibility of requiring judges, human beings, the untying of personal perceptions, experiences, principles and particular values at the time of the construction of the judicial decision. For this reason, the idea of impartiality can also be presented as a belief, based on which society maintains a minimal relationship of trust in the organs and agents that make up the justice system.
\end{abstract}

Keywords: Judicial impartiality; Procedural principle; Judicial conduct; Judicial function; Independence.

\section{Resumen}

El trabajo tiene como objetivo presentar una noción dogmática sobre el principio de imparcialidad judicial, abordándolo, en un primer momento, desde la perspectiva del proceso civil constitucional. Además, a través de una revisión bibliográfica, se buscó explicar la correspondencia internacional de este principio como una orientación de la conducta judicial, sacando a la luz, una breve contribución del derecho transnacional, así como una visión general de las principales directrices proporcionadas, por los Principios de Conducta Judicial de Bangalore. Y, en conclusión, registran se las consideraciones extraídas del estudio empírico, del cual el deber de imparcialidad se percibe como una 
orientación dogmática de difícil implementación práctica, debido al carácter humano del juez, imposibilitando valorar plenamente la exención. Así, el ideal de actuar eminentemente imparcial se reveló sólo como una orientación artificial de la conducta, por consistir en un deber impráctico en su totalidad, ya que no habría posibilidad de exigir a los jueces - seres humanos, la desvinculación de percepciones personales, experiencias, principios y valores particulares en el momento de la construcción de la decisión judicial. Por esta razón, la idea de imparcialidad también puede presentarse como una creencia, basada en la cual la sociedad mantiene una mínima relación de confianza en los órganos y agentes que conforman el sistema de justicia.

Palabras clave: Imparcialidad judicial; Principio procesal; Conducta judicial; Función judicial; Independencia.

\section{Introdução}

O Código de Processo Civil (CPC), em seu art. $1^{\circ}$, prevê a observância obrigatória, por parte do referido diploma processual, dos valores e normas fundamentais estampados na Constituição Federal, de 1988, a fim de que o processo seja ordenado, disciplinado e interpretado conforme tais diretrizes enunciadas no bojo do Texto Maior, numa relação de constante verificação de compatibilidade dos conteúdos normativos.

Para Thamay (2019), a aludida redação preambular, embora juridicamente desnecessária, revela a boa atuação do legislador, particularmente no sentido de reafirmar a indispensável interligação entre o Direito Constitucional e o Direito Processual Civil, assim como a relação imprescindível da Constituição da República com o Código de Processo Civil, percebendo-se, pois, um evidente e didático diálogo das fontes, o que reafirma o fenômeno da constitucionalização do processo civil.

Nesse sentido, Câmara (2019, p. 34) aduz que essa relação entre ambos os ramos do direito consubstancia o chamado modelo constitucional de processo civil, referindo-se ao conjunto de princípios constitucionais disciplinadores dos processos, de uma forma geral, não se restringindo à processualística civil. Como exemplo de diretrizes referentes a esse modelo constitucional de processo, o aludido autor cita os princípios da isonomia, da inafastabilidade da jurisdição, do contraditório, do juiz natural e o do devido processo legal.

O CPC, nessa toada, positivou uma série de princípios estruturais do processo, muitos dos quais encontram correspondência essencial no texto da Lei Maior. Dessa forma, dentre o eixo principiológico processual e fundamental, encontra-se a previsão do devido processo legal (due processo of law), conforme dispõe o art. $5^{\circ}$, LIV, da Constituição Cidadã. Assim, segundo o magistério de Thamay (2019), referida disposição constitucional se refere a um superprincípio, visto que dele derivam todos os demais princípios fundantes da técnica processual civil.

Sendo assim, percebe-se também ser decorrência lógica do devido processo legal o princípio do juiz natural, previsto no art. $5^{\circ}$, XXXVII e LIII, da CF/88, segundo os quais, respectivamente, "Não haverá juízo ou tribunal de exceção", e "Ninguém será processado nem sentenciado senão pela autoridade competente". A esse respeito, Pinho (2020, p. 104) leciona que o princípio do juiz natural há de ser analisado a partir de duas vertentes interdependentes, a saber, "em relação ao órgão jurisdicional e à imparcialidade".

Constata-se, pois, a importância da análise da imparcialidade como pressuposto do modelo constitucional do processo, tendo em vista, principalmente, o escrutínio de sua extensão conceitual, bem como os respectivos mecanismos processuais de contestação da parcialidade do julgador, de modo que se perscrute, com igual rigor metodológico, a relação existente entre a jurisdição, o julgador e a possibilidade concreta de assunção de imparcialidade e independência por ocasião da prática do ato decisório; motivos pelos quais se faz necessária a construção do presente artigo, baseado em revisão bibliográfica a partir da doutrina especializada. 


\section{Metodologia}

Esta pesquisa fora produzida por intermédio de metodologia especialmente voltada à revisão bibliográfica, por meio da qual se pôde compulsar notas pontuais do texto constitucional brasileiro, documentos legislativos infraconstitucionais, assim como outras disposições normativas constantes de fontes de direito internacional, num diálogo pedagógico com a essência do tema aqui pesquisado em sede de reflexão acerca do instituto processual da imparcialidade judicial no contexto do Estado Democrático de Direito.

Por oportuno, com vistas ao esclarecimento didático necessário à abordagem metodológica aqui desenvolvida, insta anotar que "A pesquisa bibliográfica é desenvolvida com base em material já elaborado, constituído principalmente de livros e artigos científicos", não se podendo olvidar que "há pesquisas científicas desenvolvidas exclusivamente a partir de fontes bibliográficas" (Gil, 2002, p. 44).

Considerou-se, para tanto, a importância da revisão bibliográfica como mecanismo metodológico relevante no que toca ao campo do saber jurídico-processual pátrio, além do diálogo teórico de fontes enredado a partir da consulta a enunciados legais de outros países, trazidos à baila pelas doutrinas especializadas na ciência do Direito. Nesse sentido, segundo Dias e Silva (2009, p. 58), "a revisão bibliográfica, que aborda os principais aspectos teóricos e práticos do tema estudado [...] tornase um alicerce indispensável para uma pesquisa de qualidade".

Esta metodologia empregada se justifica ante a premência de se levar o produto das análises teórico-práticas relacionadas à imparcialidade judicial, tanto à comunidade jurídica, quanto à sociedade em geral, tendo em vista que "O trabalho de cunho científico tem de ser útil à comunidade científica a que se dirige, bem como, numa pretensão mais alargada, a toda a comunidade" (Nunes, 2019, p. 74).

Por essas razões, além dos transcrições e elucubrações teóricas, constitucionais, infraconstitucionais e internacionais, fixou-se, também, em seção apartada, o resultado de estudo empírico acerca da percepção da observância do dever de imparcialidade judicial por parte de profissionais do Direito, de modo a aproximar os postulados dogmáticos da realidade social, particularmente em seu contexto primeiro de aplicabilidade, qual seja, a área jurídica e os intérpretes do conhecimento legal positivado.

Ainda que de forma breve, o registro dessa aproximação entre o conhecimento teórico idealmente propugnado em sede de atuação jurisdicional e a realidade jurídica se faz necessário em razão da própria natureza da atividade de pesquisa aqui desenvolvida, uma vez que "o conhecimento é um processo interativo entre o real (que se estuda) e a representação desse real na mente (pensamento concreto, construção teórica, recomposição ideal do concreto percebido ou vivido" (Beaud, 2014, p. 74).

\section{Resultados e Discussão}

\subsection{Das noções preliminares de jurisdição}

Sabe-se que o Estado é dotado de poder e exerce tal prerrogativa para fazer valer todas as pretensões em que haja manifesto interesse público. Diz-se, então, na linha de raciocínio de Dinamarco (2009, p. 104), que o Estado decide em todos os âmbitos de sua atividade, exercendo o poder nacional. Para o autor, "o Estado decide em abstrato, quando estipula as normas de conduta e de organização, e em concreto, nos campos políticos, administrativos e jurisdicional”.

Como noção preambular, no que respeita ao poder estatal de decisão, registre-se a impossibilidade de o Estado se negar a efetivar a jurisdição, tendo em vista o princípio da inafastabilidade da jurisdição, encampado no art. $5^{\circ}, \mathrm{XXXV}$, da Constituição Federal, que assevera estes termos: "A lei não excluirá da apreciação do Poder Judiciário lesão ou ameaça a direito". Demais disso, insta consignar que a jurisdição, no campo civil, será exercida pelos juízes e pelos tribunais em todo o território nacional, conforme dispõe o art. 16, do CPC. 
Na seara jurisdicional, em seu desdobramento teórico, primeiramente interessa compreender a extensão da expressão jurisdição, especialmente por ser componente intrínseco à contínua atuação estatal. Desse modo, Neves (2016, p. 80) conceitua a jurisdição "[...] como a atuação estatal visando à aplicação do direito objetivo ao caso concreto, resolvendo-se com definitividade uma situação de crise jurídica e gerando com tal solução a pacificação social".

Também há o entendimento de que "a jurisdição é exercício de influência, sem deixar de ser manifestação de poder" (Dinamarco, 2009, p. 129). Prevalece, no entanto, a ideia de que, na essência, a jurisdição consiste em "dizer o direito, no sentido de identificar a norma de direito objetivo preexistente (ou de elaborá-la, se inexistente) e de fazê-la atuar numa determinada situação" (Bermudes, 2019, p. 38).

Todavia, por didática, cumpre distinguir três aspectos a partir dos quais a jurisdição pode ser valorada. Assim, para Neves (2016), deve-se diferenciar o poder, a função e a atividade jurisdicional. Segundo o autor, em síntese, o poder jurisdicional permite o exercício da função jurisdicional, na medida em que representa o poder do Estado de intervir na esfera jurídica dos jurisdicionados; ao passo que a função jurisdicional se refere ao encargo atribuído ao Poder Judiciário pela Constituição Federal, enquanto a atividade jurisdicional diz respeito aos atos concretos praticados pelo agente estatal na condução do processo.

A propósito, uma das características da função jurisdicional é a imparcialidade do juiz, tendo em vista que "o juiz deve ser integrante de órgão do Poder Judiciário e deve ser desinteressado na lide” (Alvim, Granado \& Ferreira, 2019, p. 91); de modo a assegurar a higidez da atuação do Estado-juiz por ocasião da prestação da tutela jurisdicional adequada, a fim de que, no processo, o julgador se mantenha distante dos interesses pessoais suscitados pelas partes.

É nessa direção que se aponta que

[...] toda a arquitetura do processo, e, portanto, do debate, está a serviço da ideia de imparcialidade: o critério material de resolução é prévio ao conflito e está configurado por uma lei que é expressão dos valores majoritários; o protagonista da decisão é um terceiro predeterminado e alheio ao conflito e aos interesses das partes; e, por último, a regulação do processo procura situar as partes em litígio em posição de igualdade e facilitar-lhes os meios para que possam defender adequadamente suas pretensões, sem inclinar-se previamente, ao definir suas faculdades, por nenhuma delas (Ortiz, 2004, p. 101).

Dessa forma, depreende-se que toda a estrutura processual é moldada a partir da premissa de que, nessa relação entre os sujeitos de direito envolvidos no curso do procedimento legal, há um sujeito pré-determinado, alheio a todo e qualquer interesse particular aventado nos autos, distante das emoções suscitadas no âmago de cada pretensão, o que, por definição, configura a atuação do Estado-juiz, notadamente na condição de imparcialidade a ser ostentada pelo órgão julgador em sua atividade essencialmente deliberativa.

\subsection{Da imparcialidade judicial no direito internacional}

No que toca ao direito internacional, a garantia da imparcialidade judicial também encontra sólido respaldo normativo. Cite-se, por exemplo, a Declaração Universal dos Direitos Humanos. Esse diploma histórico traz em seu artigo 10 a seguinte redação: "Todo ser humano tem direito, em plena igualdade, a uma justa e pública audiência por parte de um tribunal independente e imparcial, para decidir seus direitos e deveres ou fundamento de qualquer acusação criminal contra ele”.

Demais disso, o Pacto de São José da Costa Rica, 22.11.1969, também designado de Convenção Americana sobre Direitos Humanos, que, como rememora Nery Junior e Nery (2018), fora aprovado pelo Decreto Legislativo $\mathrm{n}^{\circ} 27 / 92$ e mandado executar pelo Decreto $\mathrm{n}^{\circ}$ 678/92, que traz em seu bojo previsão semelhante no que concerne à garantia da existência anterior de um tribunal independente e imparcial.

Nesse ínterim, ao versar sobre as garantias judiciais, o referido Pacto prevê a seguinte redação em seu art. $8^{\circ}, \S 1^{\circ}$ : 
Toda pessoa terá o direito de ser ouvida, com as devidas garantias e dentro de um prazo razoável, por um juiz ou Tribunal competente, independente e imparcial, estabelecido anteriormente por lei, na apuração de qualquer acusação penal formulada contra ela, ou na determinação de seus direitos e obrigações de caráter civil, trabalhista, fiscal ou de qualquer outra natureza. (Brasil, 1969).

Além disso, o Pacto Internacional sobre Direitos Civis e Políticos, em seu artigo 14, 1, assevera estes termos:

Todas as pessoas são iguais perante os tribunais e as cortes de justiça. Toda pessoa terá o direito de ser ouvida publicamente e com devidas garantias por um tribunal competente, independente e imparcial, estabelecido por lei, na apuração de qualquer acusação de caráter penal formulada contra ela ou na determinação de seus direitos e obrigações de caráter civil. (Brasil, 1969).

Convém anotar que a Carta Africana de Direitos Humanos e dos Povos também sustenta a defesa da existência de um tribunal ou corte atuante com base na noção de imparcialidade, na medida em que, em seu art. $7^{\circ}$, 1, "d", assim preceitua: “1. Toda pessoa tem o direito a que sua causa seja apreciada. Esse direito compreende: (...) d) o direito de ser julgado em um prazo razoável por um tribunal imparcial”.

Nessa esteira, há também a Constituição italiana, que, no art. 111, assevera que "A jurisdição é exercida mediante o devido processo regulado pela lei. Todo o processo se desenvolve pelo contraditório entre as partes, em condições de igualdade, diante de juiz equidistante e imparcial [...]” (Nery Junior \& Nery, 2018, p. 30).

Constata-se, pois, que a existência de um julgador imparcial não é exclusividade constitucional do Brasil, uma vez que a imparcialidade judicial se trata de uma garantia dotada da característica da universalidade em relação à titularidade de direitos humanos, realidade essa que não pode ser restringida a determinados territórios de países soberanos, mas, sim, estendida a todo aquele que eventualmente se encontra sob o exercício oficial da inafastável atividade jurisdicional.

\subsection{Da concepção teórica da imparcialidade judicial}

No cenário da jurisdição e do processo, em uma realidade interdependente e necessária, torna-se imprescindível situar a imparcialidade como um dos pontos centrais do debate jurídico-científico, porque não há que se falar em tutela adequada e justa dos direitos sem que se tenham, de antemão, um juízo constituído e um juiz distanciado dos interesses das partes. Por isso, firma-se que "a imparcialidade é a nota essencial do juízo justo, pois o método de debate, o critério de decisão e o titular desta não devem ter mais interesse que a aplicação da lei” (Ortiz, 2004, p. 101).

A partir desse diálogo estabelecido entre o conteúdo constitucional e o processo civil, Medina (2020, p. 46) esclarece que "a Constituição Federal, de todo modo, ao incorporar o princípio do due processo of law, e contemplar vários de seus corolários em muitas de suas disposições, minudenciando-os, também garante a imparcialidade. A Constituição Federal contém vários dispositivos voltados a assegurar tal imparcialidade". Para tanto, continua o autor, "A causa deve ser processada e decidida por órgão jurisdicional que tenha sido previamente constituído".

De qualquer forma, “diz a constituição, a respeito, que 'ninguém será processado nem sentenciado senão pela autoridade competente' (art. 5. ${ }^{\circ}$, LIII). Veda a Constituição a criação de juízos ou tribunais de exceção (art. 5., XXXVII), criados para julgar determinado caso, garantia esta que decorre da do juiz natural” (Medina, 2020, p. 46). Todavia, na mesma lógica exposta pelo processualista paranaense, comumente se relacionam a noção da imparcialidade judicial com tantas outras garantias processuais, p. ex., a do devido processo legal, o que ressalta um diálogo entre tais fenômenos, a despeito da ausência de eventual sobreposição de um sobre o outro.

Registre-se, porém, que o debate sobre a relação entre a imparcialidade do julgador e extensão conceitual da vedação à instituição de tribunais de exceção é mais complexo do que inicialmente aparenta. Assim, a despeito da relação existente 
entre ambos os institutos processuais, notadamente sob a ótica da reflexão presente na estrutura de princípios do processo constitucional, isso "não autoriza, de forma alguma, a confusão entre esses dois campos" (Reichelt, 2015, p. 557).

Dito isso, consigne-se que "Há, de fato, uma ligação entre os fenômenos, já que a violação ao princípio do juiz natural rompe também com a garantia de imparcialidade do juiz. Não se sobrepõem, contudo: basta ver que o juiz pode ser parcial, a despeito de não haver violação ao princípio do juiz natural, ou não se tratar de tribunal de exceção" (Medina, 2020, p. 46).

De todo modo, em princípio, segundo Wambier e Talamini (2016), todo agente público deve pautar sua atuação funcional em valores como isenção e na honestidade. Essa noção de correição de conduta, no entanto, quando direcionada à figura do juiz, assume maior relevo e o debate se aprofunda. Sendo o juiz um agente jurisdicional, ele também assume o papel de terceiro estranho e alheio ao conflito levado ao seu conhecimento, a fim de que apresente uma solução jurídica.

Wambier e Talamini (2016, p. 33) afirmam que “a imparcialidade, mais do que retidão de conduta - o que também se aplica ao juiz - quer significar a sua condição de não parte, sua neutralidade, sua 'assubjetividade' (toma-se a liberdade de empregar essa palavra, que a rigor não existe em português, para transmitir uma ideia bastante precisa em italiano: asoggettività)". Logo, continuam os autores, "O juiz deve atuar com total independência, sem amarras ou vinculação a qualquer sujeito de direito, sem uma pauta política, enfim, sem qualquer outro objetivo que não o de aplicar corretamente o ordenamento jurídico".

Nas palavras de Souza (2017, p. 62), ao abordar a noção da imparcialidade sob um ponto de vista mais objetivo, distanciado de elementos valorativos íntimos, potencialmente ostentados pela figura do julgador, considera-se que "o princípio da imparcialidade reclama que o juiz atue no processo de forma objetiva, ou seja, sem que se deixe influenciar por considerações de ordem subjetiva, pessoal e antijurídica".

No que ainda diz respeito ao esclarecimento teórico da aplicação do ideal de imparcialidade, convém consignar as palavras de Vale (2019, p. 70), que observa ser um juiz imparcial "aquele que julga que forma desapaixonada, sem comprometimento com quem quer que seja. Diz respeito à retidão, à equidade e à justiça, não buscando o interesse da parte ou terceiro interessado, ou mesmo do próprio juiz".

Convém anotar que o Código de Ética da Magistratura, aprovado na $68^{a}$ Sessão Ordinária do Conselho Nacional de Justiça, do dia 06 de agosto de 2008, propõe um conceito de viés prático de imparcialidade quando estabelece, em seu art. $8^{\circ}$, que "o magistrado imparcial é aquele que busca nas provas a verdade dos fatos, com objetividade e fundamento, mantendo ao longo de todo o processo uma distância equivalente das partes, e evita todo o tipo de comportamento que possa refletir favoritismo, predisposição ou preconceito".

Apresenta-se, ainda, segundo Baptista (2020, p. 205), a perspectiva de que a imparcialidade judicial, princípio de direito processual, "se materializa na ausência de vínculos subjetivos do magistrado no processo, caracterizando-se por seu dever de se manter distante e desinteressado do processo o suficiente para conduzi-lo com isenção, sem privilegiar nenhuma das partes. É visto como um princípio, alçado à categoria de garantia processual, de justiça para as partes”.

Não sem razão, comumente se chega a um conceito basilar do princípio processual em comento, especialmente no sentido de se reconhecer que "a ideia central da imparcialidade, na visão doutrinária, corresponde ao desejo de equidistância [no sentido de distanciamento] do Juiz, em relação às partes, traduzindo-se na idealização da igualdade processual, na medida em que os magistrados não podem preferir ou privilegiar uma parte em prejuízo da outra” (Baptista, 2020, p. 205).

Neves (2016) ainda classifica a imparcialidade do juiz como pressuposto processual subjetivo, sob a justificativa de que de nada adiantaria a existência de um sujeito investido de poder jurisdicional se não houvesse a condição de imparcialidade. Com isso, o autor afirma que não se deve esperar a neutralidade do juiz, posto que tal condição é simplesmente impossível de ser verificada na realidade, haja vista que o juiz neutro é aquele que não leva para seus julgamentos as suas experiências acumuladas no curso da vida, não sofrendo, ademais, qualquer influência lícita de fora do processo. 
Todavia, deve-se atentar para a diferença entre a imparcialidade e a neutralidade. Sobre referida distinção, Didier Jr. (2015, p. 155) esclarece que "Não se pode confundir neutralidade e imparcialidade. O mito da neutralidade funda-se na possibilidade de o juiz ser desprovido de vontade inconsciente". Nesse sentido, [...] Ninguém é neutro, porque todos têm medos, traumas, preferências, experiências etc. [...] O juiz não deve, porém, ter interesse no litígio, bem como deve tratar as partes com igualdade, zelando pelo contraditório em paridade de armas (art. $7^{\circ}$, CPC): isso é ser imparcial” (Didier Jr., 2015, p. 155).

No que concerne ao referido embate processual entre as ideias de neutralidade e imparcialidade, não se pode olvidar que "o magistrado é um ser humano médio sujeito às suas emoções, às suas crenças e a seus sentimentos. Logo, não é neutro, mas detém o dever de atuação imparcial na condução do litígio. Depreende-se, então, que existem diferenças entre a imparcialidade e a neutralidade, sendo esta impossível de ser plenamente alcançada pelo homem médio" (Henriques, Silvestre \& Ferreira, 2020, p. 38).

Outra advertência é esta feita no seguinte sentido:

A imparcialidade não se confunde com a impartialidade, que exige, antes de mais nada, que o juiz seja um terceiro com relação ao conflito que decidirá. Dessa forma, antes de se analisar a imparcialidade do juiz, deve ser verificada sua impartialidade. Se for parte, está impedido de julgar não porque lhe falte imparcialidade - que no caso concreto nem deve ser analisada -, mas impartialidade. (Neves, 2016, p. 247).

A doutrina estrangeira também frisa essa diferenciação, na medida em que explicita que

[...] a impartialidade significa não ser parte no processo, contrário sensu, ser sempre juiz (terceiro), sempre terceiro. Nunca primeiro nem segundo. Porque a atribuição como primeiro no processo corresponde ao pretendente (ofendido e/ou Ministério Público) e, o segundo no processo, o resistente (imputado). Por isso, dizemos que o juiz não pode ser parte, as partes são 'pretendente e resistente”. O juiz é juiz, então, não é parte (Gutiérrez, 2014, p. 308).

Demais disso, Wambier e Talamini (2016, p. 33) ensina que "a Constituição visa a assegurar a imparcialidade dos juízes ao (i) separar os poderes e atribuir a função jurisdicional ao Poder Judiciário (art. 99 da CF); (ii) conferir garantias institucionais aos órgãos judiciários e pessoais aos magistrados (art. 95 da CF); (iii) ao estabelecer o princípio do juiz natural".

Neste ponto, anota-se que as garantias das quais os juízes são titulares são estas (art. 95, CF/88): a) vitaliciedade, que, no primeiro grau, só será adquirida após dois anos de exercício, dependendo a perda do cargo, nesse período, de deliberação do tribunal a que o juiz estiver vinculado e, nos demais casos, de sentença judicial transitada em julgado; b) inamovibilidade, saldo por motivo de interesse público, na forma do art. 93, VIII; e c) irredutibilidade de subsídio.

Essas disposições constitucionais não apenas repercutem no aspecto prático do cotidiano dos profissionais do Poder Judiciário, mas, sobretudo, sob o ângulo do comportamento pretensamente imparcial, esses preceitos enunciadores de prerrogativas são fundamentais para a construção da chamada independência interna do julgador, "que ampara os membros da carreira judiciária contra as perturbações dos demais órgãos jurisdicionais ou de seus próprios órgãos de administração" (Souza, 2017, p. 65).

Demais disso, acerca do postulado do juiz natural, igualmente extraído da Lei Fundamental, Wambier e Talamini (2016, p. 33) destacam: “também conhecido como 'princípio da vedação dos tribunais de exceção', tal princípio encontra-se estampado nos incs. XXXVII e LIII do art. $5^{\circ}$ da CF, que preveem, respectivamente, que não poderá haver juízo ou tribunal de exceção e que nenhuma pessoa poderá ser processada ou sentenciada sem que o seja pela autoridade competente".

Dessa maneira, continuam os autores, "é imprescindível que a autoridade julgadora preexista ao fato que a ela será submetido para julgamento, bem como que seja competente para tanto, a fim de que a boa qualidade da prestação jurisdicional e a imparcialidade do órgão julgador sejam asseguradas" (Wambier \& Talamini, 2016, p. 33). 
Desse modo, "do juiz exige-se imparcialidade. Não pode ele ter interesse na causa, nem ligações pessoais com os demais sujeitos do processo" (Câmara, 2019, p. 33). Nessa mesma linha, assevera-se que "o órgão julgador, representando o Estado na condução e julgamento da causa, deve agir imparcialmente e com impessoalidade; isto é, o juiz não pode ter interesse na causa a ser apreciada, sob pena de ser afastado por impedimento e suspeição" (Pinho, 2020, p. 104).

Anote-se, por didática jurídico-científica, a advertência doutrinária segundo a qual é importante diferenciar as expressões "imparcialidade do julgador" e "imparcialidade do juiz". Para Teixeira (2010, p. 333), "o nomen iuris de 'imparcialidade do julgador' em detrimento da 'imparcialidade do juiz' é mais apropriado porque sua aplicabilidade não se limita ao processo judicial, aplicando-se ao processo administrativo público e particular".

Percebe-se, então, que o juiz tem o dever de agir com imparcialidade ao conduzir os processos sob sua responsabilidade, assim como por ocasião da prolação dos atos de natureza decisória, sendo que, caso haja motivos para se contestar sua isenção, concluindo-se pela presença do vício processual da parcialidade judicial, existe a possibilidade de se afastar o julgador do processo em que atua por meio da alegação da presença de causas de suspeição ou impedimento, em vista de se garantir a incolumidade da ordem jurídica, tendo em conta que "a imparcialidade do juiz é corolário da garantia do devido processo legal" (Duarte, 2006, p. 66).

\subsection{Dos motivos de suspeição e impedimento do juiz}

No que toca à necessidade de expressa previsão legal do dever de imparcialidade, entende-se que tal mandamento de conduta judicial se encontra implícito na noção mesma da jurisdição e no exercício da atividade judicial. Por isso, registre-se que "a imparcialidade não é uma opção política pela qual o constituinte tivera que decantar e, portanto, pronunciar-se expressamente (como ocorre, e novamente o exemplo, com a independência), por outro lado, é um atributo inerente à função jurisdicional, à essência da noção mesma de ser juiz e não ser parte" (Ortiz, 2004, p. 101).

No entanto, até mesmo por questão de segurança jurídica decorrente da positivação, e com o objetivo de preservar o dever de imparcialidade do agente jurisdicional, "enumera o CPC uma série de situações em que se considera haver algum tipo de parcialidade que macula a participação do magistrado no processo" (Câmara, 2019, p. 34). Assim, duas são as causas de afastamento do juiz do processo, por motivo de vício de parcialidade, a saber, a suspeição e o impedimento.

Nesse compasso, o próprio CPC se revele bastante didático ao diferenciar os motivos ensejadores de parcialidade por parte do juiz, razão pela qual se pode facilmente realizar o enquadramento da situação fática casualmente questionada e, por conseguinte, aferir a real extensão e intensidade do eventual descumprimento do princípio (e dever) de imparcialidade.

Por isso, "o Código disciplina as hipóteses em que o juiz deve ter tido por não imparcial (impedimento - art. 144 - e suspeição - art. 145), atribuindo-lhes consequências distintas, permitindo a rescisão de sentença proferida por juiz impedido (art. 966, II)". Esclareça-se, pois, que "a norma do art. 966, II, está ligada ao disposto no art. 139, I, do CPC, já que a necessidade de dispensar tratamento igualitário às partes pressupõe que o juiz seja equidistante delas, isto é, que o juiz seja imparcial" (Alvim, Granado \& Ferreira, 2019, p. 91).

Importa anotar o conteúdo dos dispositivos legais acima transcritos, de modo que, no que tange ao art. 966, II, do CPC, "A decisão de mérito, transitada em julgado, pode ser rescindida quando: [...] II - for proferida por juiz impedido ou por juízo absolutamente incompetente". No mais, "o juiz dirigirá o processo conforme as disposições deste Código, incumbindolhe: I - assegurar às partes igualdade de tratamento" (art. 139, I, CPC).

Por didática, cumpre arrolar os motivos ensejadores de impedimento da atuação judicial, todos previstos nos incisos do art. 144, do CPC, in verbis: 
Há impedimento do juiz, sendo-lhe vedado exercer suas funções no processo: I - em que interveio como mandatário da parte, oficiou como perito, funcionou como membro do Ministério Público ou prestou depoimento como testemunha; II - de que conheceu em outro grau de jurisdição, tendo proferido decisão; III - quando nele estiver postulando, como defensor público, advogado ou membro do Ministério Público, seu cônjuge ou companheiro, ou qualquer parente, consanguíneo ou afim, em linha reta ou colateral, até o terceiro grau, inclusive; IV - quando for parte no processo ele próprio, seu cônjuge ou companheiro, ou parente, consanguíneo ou afim, em linha reta ou colateral, até o terceiro grau, inclusive; V - quando for sócio ou membro de direção ou de administração de pessoa jurídica parte no processo; VI - quando for herdeiro presuntivo, donatário ou empregador de qualquer das partes; VII em que figure como parte instituição de ensino com a qual tenha relação de emprego ou decorrente de contrato de prestação de serviços; VIII - em que figure como parte cliente do escritório de advocacia de seu cônjuge, companheiro ou parente, consanguíneo ou afim, em linha reta ou colateral, até o terceiro grau, inclusive, mesmo que patrocinado por advogado de outro escritório; e IX - quando promover ação contra a parte ou seu advogado. (Brasil, 2015).

A suspeição, por outro lado, encontra-se nos incisos do art. 145, que assim dispõe:

Há suspeição do juiz: I - amigo íntimo ou inimigo de qualquer das partes ou de seus advogados; II - que receber presentes de pessoas que tiverem interesse na causa antes ou depois de iniciado o processo, que aconselhar alguma das partes acerca do objeto da causa ou que subministrar meios para atender às despesas do litígio; III - quando qualquer das partes for sua credora ou devedora, de seu cônjuge ou companheiro ou de parentes destes, em linha reta até o terceiro grau, inclusive; e IV - interessado no julgamento do processo em favor de qualquer das partes. (Brasil, 2015).

No entender de Wambier e Talamini (2016, p. 152), faz-se essa distinção porque "Há presunção legal de que a imparcialidade possa estar comprometida nos casos em que a própria lei prevê motivos para o impedimento do juiz", ao passo que "os casos que a lei arrola como sendo de suspeição (art. 145 do CPC/2015) também podem influir na imparcialidade do juiz. No entanto, não o fazem a ponto de comprometer o pressuposto processual de imparcialidade”, de modo que, "ainda que o juiz seja suspeito, não se considera estar ausente o pressuposto processual da imparcialidade. Por isso, se a suspeição não for oportunamente alegada, reputa-se afastada qualquer invalidade sob o prisma da imparcialidade do juiz" (Wambier \& Talamini, 2016, p. 152).

\subsection{Da imparcialidade segundo os Princípios de Bangalore de Conduta Judicial}

No que se refere às diretrizes inerentes à atuação das autoridades judiciárias, têm-se os Princípios de Bangalore de Conduta Judicial, elaborados pelo Grupo de Integridade Judicial, constituído sob os auspícios da Organização das Nações Unidas (ONU), sendo posteriormente traduzidos e editados pelo Centro de Estudos Judiciários do Conselho da Justiça Federal; sendo que, conforme o próprio documento oficial da ONU, "sua elaboração teve início no ano de 2000, em Viena (Áustria), os princípios foram formulados em abril de 2001, em Bangalore (Índia) e oficialmente aprovados em novembro de 2002, em Haia (Holanda)" (2008).

Na esteira dos Comentários aos Princípios de Bangalore, empreendidos pela ONU (2008, p. 7), cumpre esclarecer que “os Princípios de Conduta Judicial de Bangalore é um projeto de Código Judicial em âmbito global, elaborado com base em outros códigos e estatutos, nacionais, regionais e internacionais, sobre o tema, dentre eles a Declaração Universal dos Direitos Humanos, da ONU”. Como pressuposto, a ONU (2008, p. 7) prega que "a confiança do público no sistema judicial também é de fundamental importância para que este mantenha sua independência, que dirá respeito às cortes e ao próprio magistrado, e não veja seus limites serem invadidos pelos demais poderes governamentais, das mais variadas formas, com a aquiescência da própria população".

A importância de se afirmar princípios norteadores da conduta judicial ganha especial destaque ante a realidade dos regimes democráticos na contemporaneidade, seja no âmbito interno, como instrumento de preservação da ordem doméstica, seja na seara internacional, como ferramenta de pacificação social da comunidade global. Por isso, com fulcro nas disposições da ONU (2008, p. 9), defende-se que "um judiciário de incontestável integridade é a instituição base, essencial, para assegurar 
a conformidade entre a democracia e a lei. Mesmo quando todas as restantes proteções falham, ele fornece uma barreira protetora ao público contra quaisquer violações de seus direitos e liberdades garantidos pela lei”.

Nesse diapasão, urge apontar o primeiro valor constante dos Princípios de Bangalore de Conduta Judicial, a independência, vez que tal condição é indispensável para a efetivação de um comportamento judicial imparcial. Logo, no campo internacional por excelência, o princípio da independência é apresentado pela ONU nestes termos: "A independência judicial é um pré-requisito do estado de Direito e uma garantia fundamental de um julgamento justo. Um juiz, consequentemente, deverá apoiar e ser o exemplo da independência judicial tanto no seu aspecto individual quanto no aspecto institucional" (2008, p. 45).

No âmbito da atuação judicial dotada de imparcialidade, a independência do juiz é considerada uma prerrogativa individual, sendo, inclusive, “[...] a responsabilidade imposta sobre cada juiz para habilitá-lo a julgar honesta e imparcialmente uma disputa com base na lei e na evidência, sem pressões externas ou influência e sem medo de interferência de quem quer que seja" (ONU, 2008, p. 45). Diante disso, prega-se que "o cerne do princípio da independência judicial é a completa liberdade do juiz para ouvir e decidir as ações impetradas na corte. Nenhum estranho, seja governo, grupo de pressão, indivíduo ou mesmo um outro juiz deve interferir, ou tentar interferir, na maneira como um juiz conduz um litígio e sentencia" (ONU, 2008, p. 45).

A enunciação acima referida é relevante, porque os institutos da independência e da imparcialidade guardam estreita relação, em especial na análise contextualizada da atividade jurisdicional eficazmente desenvolvida. Todavia, por razão teórica, insta apresentar a distinção didática apontada no bojo dos comentários feitos aos Princípios de Conduta Judicial de Bangalore, propalado pelas Nações Unidas.

Assim, conforme as diretivas da ONU (2008, p. 46), estabelece-se que "a imparcialidade se refere a um estado de espírito ou atitude do tribunal em relação aos assuntos e às partes em um caso em particular. A palavra imparcial conota abstenção de parcialidade, real ou aparente". Noutra banda, "A palavra independência reflete ou incorpora o tradicional valor constitucional de independência. Desse modo, ela conota não um mero estado mental ou atitude no real exercício das funções judiciais, mas um status ou relação com os outros, particularmente como o ramo executivo do governo, que se funda em condições objetivas ou garantias".

Segundo a ONU (2008, p. 53), tal verificação de correspondência de pressupostos do ofício relativo à prática da jurisdição também se fundamenta na ideia de que "A independência judicial pressupõe total imparcialidade por parte do juiz. Ao decidir em favor de qualquer das partes, um juiz deve ser livre de qualquer conexão, inclinação ou parcialidade que afete ou possa ser vista como capaz de afetar - sua habilidade para julgar independentemente".

Nessa esteira, nota-se que "a independência é necessária precondição da imparcialidade. É um pré-requisito para se obter o objetivo da imparcialidade. Um juiz pode ser independente, sem, no entanto, ser imparcial (em um caso específico), mas um juiz que seja independente não pode, por definição, ser imparcial (em uma base institucional)" (ONU, 2008, p. 65).

Com base nas enunciações da ONU (2008, p. 65), assentadas tais noções alicerçais sobre o impacto da independência judicial, calha trazer a lume o princípio da imparcialidade (valor 2), sob a ótica dialógica dos Princípios de Conduta Judicial de Bangalore, a partir do qual se extrai que "a imparcialidade é essencial para o apropriado cumprimento dos deveres do cargo de juiz. Aplica-se não somente à decisão, mas também ao processo de tomada de decisão"

Nesse mote, a doutrina estrangeira busca conciliar a temática e justificar a coexistência de ambos os institutos jurídico-processuais, realçando a natureza de complementariedade, condição necessária para a valoração conjunta das expressões em tela, de modo que "a imparcialidade judicial, como dizíamos, está estreitamente vinculada com o princípio da independência. E, ademais, com o fim de garantir esse princípio de independência, mas também com a finalidade de evitar a colisão de interesses que possa estar na raiz de um defeito de parcialidade do juiz, é como se constrói todo o sistema de incompatibilidades judiciais" (Asensio, 2012, p. 32). 
Acerca da forma como se dá a percepção do princípio em comento, a ONU (2008, p. 65) proclama que "A imparcialidade é a qualidade fundamental requerida de um juiz e o principal atributo do Judiciário", devendo, pois, "existir tanto como uma questão de fato como uma questão de razoável percepção". A partir dessa prática de constatação presente nos Comentários ao Princípios de Bangalore, a ONU (2008, p. 65-66) estabelece que "se a parcialidade é razoavelmente percebida, essa percepção provavelmente deixará um senso de pesar e de injustiça realizados destruindo, consequentemente, a confiança no sistema judicial". Considera-se, para tanto, ser a imparcialidade idealmente percebida "pelos padrões de um observador razoável”.

Além do mais, consoante os registros da ONU (2008, p. 66), a Corte Europeia assentou dois aspectos da exigência da imparcialidade. Num primeiro momento, "o tribunal deve ser subjetivamente imparcial, i.e., nenhum membro do tribunal deve deter qualquer preconceito ou parcialidade pessoais. A imparcialidade pessoal deve ser presumida a menos que haja evidência em contrário". E, em análise derradeira, impõe-se que "o tribunal deve ser imparcial a partir de um ponto de vista objetivo, i. e., ele deve oferecer garantias suficientes para excluir qualquer dúvida legítima a seu respeito". Dessa forma, "deve-se determinar se, não obstante a conduta pessoal do juiz, há determinados fatos que podem levantar dúvidas acerca de sua imparcialidade".

\subsection{Do princípio da imparcialidade como uma crença impraticável}

Por ser a condição de imparcialidade exigida do juiz, um ser humano, e não do órgão jurisdicional propriamente dito, parte do aparato estatal, uma das controvérsias emergentes neste contexto se situa justamente na indagação, legitimamente construída, a respeito de quão verdadeira e creditável é a exigência jurídico-processual direcionada ao magistrado, particularmente no sentido de se exigir desse ser humano a quase plenitude de isenção em relação a valores e concepções pessoais de vida por ocasião do ato de julgar, de modo que sua percepção não exerça influência indevidas no resultado do julgamento por ele efetuado.

Por essa razão, diz-se que "um dos maiores dilemas da atuação dos magistrados está no difícil equilíbrio de viver entre o dever de parecerem imparciais e o fato de serem humanos" (Baptista, 2020, p. 205). Diante disso, a doutora Bárbara Gomes Lupetti Baptista (2020) realizou um estudo de natureza empírica, por ocasião de sua pesquisa científica durante a fase de doutoramento, oportunidade em que entrevistou diversos profissionais do Direito (cerca de 80 interlocutores, principalmente magistrados), a ponto de obter variadas - e, não raramente, convergentes - percepções acerca da correspondência entre o mandamento da imparcialidade e a verificação prática da observância de referida diretriz processual.

Constatou-se, aliás, “[...] que, entre o dever de parecerem imparciais e o fato de serem humanos, os magistrados transitam em um sistema de crenças de sua própria imparcialidade, construído discursivamente pelo campo do direito, e que funciona como uma categoria estruturante do sistema judiciário, que desloca e centraliza no magistrado, o poder de interpretar e de decidir, no caso concreto, o que significa 'fazer justiça"' (Baptista, 2020, p. 203).

Partindo-se da premissa fática de que "o discurso sobre a imparcialidade judicial como garantia processual e como pressuposto de validade do processo é tão recorrente quanto as críticas sobre a sua impossibilidade e falta de concretude", a autora ouviu de seus interlocutores que a imparcialidade judicial pode ser perfeitamente alocada à categoria de “'mito', 'quimera', 'fábula', 'utopia', 'fantasia'” (Baptista, 2020, p. 209).

Porém, este é um relato que consubstancia toda a roupagem de crença que se atribui ao dever de imparcialidade: "se o judiciário assume que o juiz não consegue ser imparcial, o sistema vai falir. Acaba o sistema. As pessoas têm que acreditar que ali tem um juiz imparcial, senão (sic) ninguém mais vai ao Judiciário para resolver seus problemas; vão resolver tudo sozinhos" (Baptista, 2020, p. 209). 
De certo modo, sobre a verificação da percepção prática da efetividade do enunciado abstrato da imparcialidade, conclui-se que

Trata-se de uma crença, construída discursivamente pelo campo do direito [constituído por legisladores, doutrinadores e profissionais], que é configurada como uma categoria estruturante do sistema, sem a qual o Judiciário "fecharia suas portas" [...]. Ela é um dever inerente à função, mas, ao mesmo tempo, um mito, uma quimera, uma fábula ou uma utopia que os magistrados [e os profissionais do sistema de justiça] devem se esforçar para manter viva" (Baptista, 2020, p. 210).

Portanto, a despeito de toda a sua carga axiológica e valorativa, assente como elemento integrante do ideário informador do sistema de justiça pátrio, infere-se que o princípio, ou dever, de imparcialidade judicial, além de ser um mandamento extraído do regramento processual, com respaldo constitucional, igualmente revela seu teor programático, fundante, também, de uma crença lançada à sociedade, a fim de que os cidadãos se mantenham convencidos de que os juízes consigam se manter totalmente isentos de influências perceptíveis e que recaem sobre todo e qualquer ser humano, sob a justificativa de que o fato de acreditar nesse mito pode conservar, de certo modo, a credibilidade e a confiança social no Poder Judiciário.

\section{Conclusão}

O princípio (e/ou dever) de imparcialidade judicial pode ser concebido a partir da análise do texto constitucional, mormente sob a luz do princípio do juiz natural, pressupondo-se o instituto da jurisdição e todos os seus desdobramentos em termos materiais e processuais. Tendo a jurisdição e o processo civil uma relação necessária de correspondência com os enunciados fundamentais em sede do Texto Maior, a observância da prática processual a partir da constitucionalização de valores e normas estruturais de procedimento é realidade que se impõe no cotidiano forense.

A imparcialidade, enquanto dever ser, aplicada à atuação judicial, trata-se de uma orientação de conduta que não se restringe ao ordenamento pátrio, encontrando ressonância robustecedora em disposições componentes do direito internacional. Da Declaração Universal dos Direitos Humanos à Carta de Banjul, a atuação imparcial da autoridade judiciária é revelada de forma mais abrangente do que a habitualmente propagada, de modo a transcender a configuração de mandamento estritamente direcionado ao agente jurisdicional, integrando, por conseguinte, o rol de direitos fundamentais titularizado pelos cidadãos, os quais possuem o direito de que suas causas sejam conhecidas, processadas, apreciadas e decididas por juízes e cortes independentes e imparciais.

A despeito de as noções de imparcialidade e independência serem aparentemente cindidas por força da didática por ocasião da exposição teórica, essas diretrizes, na prática, são complementares e interdependentes; isto é, de certa forma, a independência é um pré-requisito para a constatação da imparcialidade presente na conduta judicial. Aliás, pelos Princípios de Bangalore de Conduta Judicial, a imparcialidade judicial é fundamental para a construção e manutenção da integridade do Poder Judiciário como instrumento indispensável à concretização dos ideais democráticos e à efetivação das leis.

A mesma imparcialidade, todavia, pode ser questionada a partir da extensão de sua observância no momento do ato decisório, particularmente por se pretender a isenção do julgador ante os casos concretos levados à sua apreciação. Dessa forma, foi realizado um estudo empírico com profissionais do Direito em que se constatou a percepção de prevalência do ideal de atuação eminentemente imparcial apenas como uma orientação artificial de comportamento, em virtude de consistir num dever impraticável em sua totalidade, uma vez que não haveria possibilidade de se exigir de juízes, seres humanos, a desvinculação de percepções pessoais, experiências, princípios e valores particulares por ocasião da construção da decisão 
judicial. Por essa razão, a ideia da imparcialidade também pode ser apresentada como uma crença, com base na qual a sociedade mantém a mínima relação de confiança nos órgãos e nos agentes que integram o sistema de justiça.

Por fim, a título de pesquisas científicas futuras, sugere-se a extensão do estudo da imparcialidade para outras searas de atuação institucional no âmbito do poder público, em que também se exige um comportamento ético e neutro, a fim de individualizar a análise do referido instituto em outras atividades oficiais, bem como evidenciar tão somente o dever funcional de se perseguir o interesse coletivo, desprendendo-se dos anseios particulares e estranhos ao funcionamento do aparelho estatal, tendo em vista as diretrizes aplicáveis ao contexto da Administração Pública em sua inteireza, por força da Constituição Federal brasileira, de 1988.

\section{Referências}

Alvim, E. A., Granado, D. W. \& Ferreira, E. A. (2019). Direito processual civil. Saraiva Educação.

Asensio, R. J. (2012). Imparcialidad judicial: su proyección sobre los deberes (código de conducta) y derechos fundamentales del juez. In Arnaiz, A. S. (Ed.), Los derechos fundamentales de los jueces (p. 29-48). Madrid: Marcial Pons.

Baptista, B. G. L. (2020). A crença no princípio (ou mito) da imparcialidade judicial. Revista de Estudos Empíricos em Direito (REED), 7(2), $203-223$.

Beaud, M. (2014). A arte da tese: como elaborar trabalhos de pós-graduação, mestrado e doutorado. BestBolso.

Bermudes, S. (2019). Introdução ao processo civil. Forense.

Brasil. (1992). Decreto n 678, de 6 de novembro de 1992. Promulga a Convenção Americana sobre Direitos Humanos (Pacto de São José da Costa Rica), de 22 de novembro de 1969. http://www.planalto.gov.br/ccivil_03/decreto/d0678.htm

Brasil. (1988). Constituição da República Federativa do Brasil. Promulgada em 5 de outubro de 1988. http://www.planalto.gov.br/ccivil_03/cons tituicao/constituicao.htm

Brasil. (2015). Lei no 13.105, de 15 de março de 2015. Código de processo civil. http://www.planalto.gov.br/ccivil_03/_ato2015-2018/2015/lei/113105.htm

Brasil. (1992). Decreto $\mathrm{n}^{\text {o }}$ 592, de 6 de julho de 1992. Atos internacionais. Pacto Internacional sobre Direitos Civis e Políticos. http://www.planalto.gov.br/ccivil_03/decreto/1990-1994/d0592.htm

Brasil. (1948). UNICEF. Declaração Universal dos Direitos Humanos: adotada e proclamada pela Assembleia Geral das Nações Unidas (resolução 270 A III) em 10 de dezembro de 1948. https://www.unicef.org/brazil/declaracao-universal-dos-direitos-humanos

Câmara, A. F. (2019). O novo processo civil brasileiro. Atlas.

Carta De Banjul. (1981). Carta Africana dos Direitos Humanos e dos Povos. Aprovada pela Conferência Ministerial da Organização da Unidade Africana (OUA) em Banjul, Gâmbia, em janeiro de 1981, e adotada pela XVIII Assembléia dos Chefes de Estado e Governo da Organização da Unidade Africana (OUA) em Nairóbi, Quênia, em 27 de julho de 1981. http://www.dhnet.org.br/direitos/sip/africa/banjul.htm

Conselho Nacional De Justiça (2008). Código de Ética da Magistratura Nacional. Aprovado na $68^{a}$ Sessão Ordinária do Conselho Nacional de Justiça, do dia 06 de agosto de 2008, nos autos do Processo n ${ }^{\circ}$ 200820000007337. Diário de Justiça, Brasília, 18 de setembro de 2008. https://www.cnj.jus.br/codigo-de-eticada-magistratura/

Dias, D. de S. \& Silva, M. F. (2009). Como escrever uma monografia. UFRJ/COPPEAD.

Didier Jr., F. (2015). Curso de direito processual civil: introdução ao direito processual civil, parte geral e processo de conhecimento. Salvador: Jus Podivm.

Dinamarco, C. R. (2009). A instrumentalidade do processo. Malheiros.

Duarte, R. P. (2006). Pré-julgamento e suspeição do julgador. Revista de Processo, 138, 56-77.

Gil, A. C. (2002). Como elaborar projetos de pesquisa. Atlas.

Gutiérrez, N. H. (2014). Los dilemas éticos de un juez y su imparcialidade judicial. In Calvinho, G.et al. (Ed.), Derecho procesal garantista y constitucional: processo, garantía y libertad (p. 301-322). Medellín: Corporación Universitaria Remington.

Henriques, F. S. G., Silvestre, G. F. \& Ferreira, T. L. (2020). O art. 331 do código de processo civil e a imparcialidade objetiva do juiz no processo civil: para além das hipóteses de suspeição e de impedimento. Revista de Processo, 308, 35-55.

Medina, J. M. G. (2020). Curso de direito processual civil moderno. Thomson Reuters Brasil.

Nery Junior, N. \& Nery, R. M. de A. (2018). Código de processo civil comentado. Thomson Reuters Brasil.

Neves, D. A. A. (2016). Manual de direito processual civil: volume único. JusPodivm. 
Research, Society and Development, v. 10, n. 13, e103101321059, 2021

(CC BY 4.0) | ISSN 2525-3409 | DOI: http://dx.doi.org/10.33448/rsd-v10i13.21059

Nunes, R. (2019). Manual de monografia jurídica. Rio de Janeiro.

Organização das Nações Unidas (2008). Escritório Contra Drogas e Crime (Unodc). Comentários aos Princípios de Bangalore de Conduta Judicial. Tradução de Marlon da Silva Malha e Ariane Emílio Kloth. Brasília: Conselho da Justiça Federal. https://www.unodc.org/documents/lpobrazil/Topics_corruption/Publicacoes/2008_Comentarios_aos_Principios_de_Bangalore.pdf

Ortiz, I. V. (2004). Imparcialidad del juez y médios de comunicación. Tirant lo Blanch.

Pinho, H. D. B. de. (2020). Manual de direito processual civil contemporâneo. Saraiva Educação.

Reichelt, L. A. (2015). O direito fundamental das partes à imparcialidade do juiz no direito processual civil. Revista de Processo, $227,105-122$.

Souza, A. C. de. (2017). Imparcialidade do juiz: similitudes e diferenciação em relação aos demais princípios constitucionais. Revista de Processo, $270,57-83$.

Souza, A. C. de. (2017). Imparcialidade do juiz - uma leitura constitucional de sua concepção dogmática. Revista de Processo, $269,59-88$.

Teixeira, W. de B. L. (2010). O princípio da imparcialidade do julgador como garantia fundamental e seus efeitos no processo. Revista de Processo, 186, 333 352.

Thamay, R. F. K. (2019). Manual de direito processual civil. Saraiva Educação.

Vale, I. P. do. (2019). O princípio da imparcialidade do juiz em face do sistema acusatório brasileiro. Revista dos Tribunais, 1007, 67-93.

Wambier, L. R. \& Talamini, E. (2016). Curso avançado de processo civil: teoria geral do processo. Revista dos Tribunais. 